\title{
Gimme Shelter: ABODO's Slocum Talks About his Apartment- Hunting Breakthrough
}

\author{
Jon Eckhardt (University of Wisconsin-Madison)
}

KEYWORDS: Real Estate, Rental, Leasing, Strategy, Startups, student entrepreneurs, Student innovators.

Alec Slocum started his smartphone-based apartmenthunting service, ABODO, after being frustrated in his own search for shelter. He sat down recently with Jon Eckhardt to talk about how he launched his business, the importance of getting things done rather than agonizing over business plans, and why good mentors and complementary teammates are as important as good roommates. 